\title{
Immune System Response in Alzheimer's Disease
}

\author{
P.L. McGeer, H. Akiyama, S. Itagaki and E.G. McGeer
}

\begin{abstract}
Involvement of the immune system in the pathogenesis of Alzheimer's disease was demonstrated in two ways: by the attachment of complement proteins to diseased tissue, and by the activation of cells associated with the immune system. Alzheimer brain tissue was stained immunohistochemically by antibodies to components of the classical, but not the alternative, complement pathway. Antibodies to Clq, C3d, and C4d stained senile plaques, dystrophic neurites, neuropil threads and some tangled neurons. Antibodies to a neoantigenic site on the C5b-9 membrane attack complex stained dystrophic neurites and many tangled neurons, but not senile plaques. Antibodies to Factor $\mathrm{P}$ and fraction Bb of Factor B, which are specific for the alternative complement pathway, did not stain Alzheimer brain tissue. The cellular immune response was evaluated by the presence of reactive microglia and by the infiltration of small numbers of T-cells into diseased brain tissue. Reactive microglia were identified by antibodies to HLA-DR, a class II major histocompatibility complex glycoprotein, and by enhanced staining with antibodies to leukocyte com-

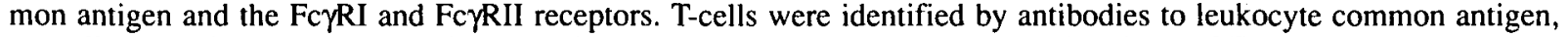
as well as the CD4 and CD8 surface proteins. Double immunostaining with antibodies to GFAP and MHC class I or class II antigens established that astrocytes, which are GFAP positive, do not express MHC antigens in Alzheimer's disease. Endothelial cells express MHC class I antigens while reactive microglia and some leukocytes express class II antigen.
\end{abstract}

\begin{abstract}
RÉSUMÉ: La réponse immunitaire dans la maladie d'Alzheimer L'implication du système immunitaire dans la pathogénèse de la maladie d'Alzheimer a été démontrée de deux façons: par la fixation de protéines du complément au niveau du tissu atteint et par l'activation de cellules associées au système immunitaire. Le tissu cérébral de patients atteints de la maladie d'Alzheimer (MA) a été coloré par immunohistochimie au moyen d'anticorps dirigés contre des composantes de la voie classique, et non de la voie alterne, d'activation du complément. Les anticorps dirigés contre $\mathrm{Clq}, \mathrm{C} 3 \mathrm{~d}$ et $\mathrm{C} 4 \mathrm{~d}$ coloraient les plaques séniles, les neurites dystrophiques, les fils neuropiles et quelques neurones contenant des amas neurofibrillaires. Des anticorps à un site néo-antigénique sur le complexe s'attaquant à la membrane C5b-9 colorait des neurites dystrophiques et plusieurs neurones contenant des amas neurofibrillaires, et non les plaques séniles. Les anticorps au Facteur $\mathrm{P}$ et la fraction $\mathrm{Bb}$ du Facteur $\mathrm{B}$, qui sont spécifiques pour la voie alterne d'activation du complément, ne coloraient pas le tissu cérébral de patients atteint de MA. La réponse immunitaire cérébrale a été évaluée par la présence de microglie réactionnelle et par l'infiltration d'un petit nombre de cellules $\mathrm{T}$ dans le tissu cérébral malade. La microglie réactionnelle a été identifiée par des anticorps dirigés contre le HLA-DR une glycoprotéine de classe II du complexe majeur d'histocompatibilité, et par une coloration soutenue au moyen d'anticorps

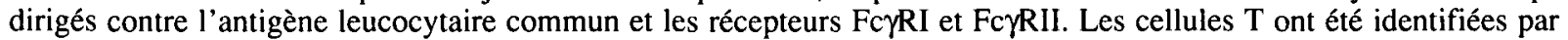
des anticorps dirigés contre l'antigène leucocytaire commun, ainsi que contre les protéines de surface CD4 et CD8. Une double coloration immunologique avec des anticorps dirigés contre la GFAP et les antigènes NHC de classe I ou de classe II a montré que les astrocyte, qui sont GFAP positifs n'expriment pas d'antigène MHC dans la MA. Les cellules endothéliales expriment des antigènes MHC de classe I, alors que la microglie réactionnelle et certains leucocytes expriment des antigènes de classe II.
\end{abstract}

Can.J. Neurol. Sci. 1989; 16:516-527

Involvement of the immune system in the pathogenesis of Alzheimer's disease (AD) has been suspected for many years. Initially, the presence of IgG in senile plaques was reported by Ishii et al. ${ }^{1}$ Subsequently, Ishii and colleagues $2-5$ and several other groups obtained similar results. ${ }^{6-9}$ Nevertheless, the significance of this finding has remained uncertain. Immunohistochemical staining of pathological tissue for immunoglobulins has been neither strong nor consistent.
Moreover, positive staining has also been obtained for other serum proteins in $A D$ brain tissue, and for $\operatorname{IgG}$ and other serum proteins in multi-infarct dementia. ${ }^{9}, 10$ Serum infiltrating tissue from leaky vessels has been suggested as an alternative mechanism. $8-10$

More convincing evidence of an immune response in $\mathrm{AD}$ is a series of reports of complement proteins being associated with senile plaques, leptomeninges and congophilic vessels. This is a

From the Kinsmen Laboratory of Neurological Research, Department of Psychiatry, University of B.C., Vancouver Reprint requests to: Dr. Patrick L. McGeer, Kinsmen Laboratory, University of B.C., 2255 Wesbrook Mall, Vancouver, British Columbia, Canada V6T 1W5 
potentially important corollary finding because the classical complement cascade is usually initiated by interaction of antibody with antigen. Eikelenboom and Stam 6 first reported immunohistochemical evidence for the presence of $\mathrm{Clq}, \mathrm{C} 3 \mathrm{~b}$, $\mathrm{C} 3 \mathrm{c}, \mathrm{C} 3 \mathrm{~d}$ and $\mathrm{C} 4$ in senile plaques. Several groups subsequently confirmed the presence of $\mathrm{Clq}, \mathrm{C} 3$ and $\mathrm{C} 4$ in association with amyloid deposits in AD. $3,4,8,9,11$ Nevertheless, Eikelenboom et al $^{8}$ have argued that complement activation in vivo is probably not initiated by an antigen-antibody reaction because of the questionable nature of the IgG immunohistochemical data. They have suggested instead the existence of some nonimmunological activation mechanism. It is known that trypsin-like enzymes and other non-immunologic factors can initiate the classical complement reaction. 12

The alternative complement pathway seems not to be involved. Properdin, a factor specific for the alternative complement pathway, has been reported not to be present in AD tissue.3,6 Negative evidence has also been obtained for the presence of complement components C5-C9 which are associated with the membrane attack complex. ${ }^{3,4,8}$

To summarize these studies, evidence of an equivocal nature has been obtained for the presence of immunoglobulins in association with $\mathrm{AD}$ senile plaques. Much stronger evidence has been obtained for the presence of the C1-C4 components of the classical complement pathway in association with amyloid deposits, but the significance of this finding is still uncertain.

If the immune system is activated in $A D$, it would be anticipated that increased numbers of tissue macrophages and infiltration of tissue by T-cells would be observed. Since T-cells are restricted in their functional activity by major histocompatibility complex (MHC) antigens, also referred to as human leukocyte antigens (HLAs), cells expressing these surface glycoproteins should also be present. Brain tissue is known to express MHC antigens poorly, which is one of the reasons it is said to be immunologically privileged. ${ }^{13}$ However, it has now been shown that in AD some cells vigorously express the MHC class II surface glycoprotein HLA-DR. ${ }^{14-16}$ These cells are predominantly reactive microglia, and are found to be strongly associated with senile plaques. ${ }^{14-17}$ A classical function of HLA-DR is to present "foreign" antigen to T-helper inducer (T4 or CD4 lymphocytes) in order to stimulate an immune response against that antigen. ${ }^{18}$ The expression of HLA-DR or other immunity associated (Ia) glycoproteins by a cell does not necessarily indicate that this process is taking place. Many reports exist of these surface proteins being expressed in apparently non-pathological tissue. Nevertheless, such expression is considered an essential prerequisite for $\mathrm{T}$-cell participation in an immune response. Furthermore, the presence of T-helper inducer and T-cytotoxic suppressor (T8 or CD8) lymphocytes has also been reported in AD tissue. 19,20 Thus, the appropriate tissue elements for a cell mediated immune response have been confirmed to be present in $\mathrm{AD}$ brain tissue.

In this paper we report much more detailed evidence for the presence of complement in AD brain tissue and for the presence of an accompanying cellular immune response. We find that all of the major components of the classical, but not the alternative, complement pathway are present. We also find that reactive microglia expressing HLA-DR, the MHC class II glycoprotein associated with antigen presentation, occur in complement rich areas of $A D$ brain. These reactive microglia also express high levels of the FcyRI and FcyRII receptors that are associated with phagocytosis of immune complexes. We further find lymphocytes positive for the CD4 and CD8 surface antigens characteristic of the T-helper-inducer and T-cytotoxic suppressor subclasses are present in affected AD tissue.

\section{Methods and Results}

The various antibodies which have been used in this study, the conditions for staining, and the results obtained are summarized in Table 1. For the classical complement pathway, antibodies to the specific components $\mathrm{Clq}$ and $\mathrm{C} 4 \mathrm{~d}$ were used. For the alternative complement pathway, antibodies to properdin and fraction $\mathrm{Bb}$ of Factor $\mathrm{B}$ were selected. For the opsonizing C3 component, anti-C3d was used. For the membrane attack complex, antibodies to $\mathrm{C} 7, \mathrm{C} 9$ and a neoantigenic site on $\mathrm{C} 5 \mathrm{~b}-9$ were utilized.

As immune cellular markers, antibodies were employed to the MHC group II glycoprotein HLA-DR; to the common structural component of MHC class I glycoproteins, HLA-A,B,C; to the FcrRI and FcrRII receptors; to leukocyte common antigen; and to the CD4 and CD8 T-cell surface proteins. Astrocytes were detected by antibody to glial fibrillary acidic protein (GFAP), and extracellular amyloid by staining with a highly sensitive modification to the Bielschowsky's silver stain.

Tissue from ten AD and four cases without neurological complication were examined in this study. Brains were obtained from 2 to 12 hours after death. Small samples were dissected from the temporal cortex, including the hippocampus, and other cortical areas and placed immediately in cold $4 \%$ buffered paraformaldehyde to achieve rapid fixation. After two days they were transferred to a maintenance solution of $15 \%$ sucrose in $0.1 \mathrm{M}$ phosphate buffered saline (PBS) until sectioning. Sections were cut on a freezing microtome at $30 \mu \mathrm{m}$ thickness and collected in PBS containing $0.3 \%$ Triton $\mathrm{X}-100$. They were pretreated with $\mathrm{H}_{2} \mathrm{O}_{2}$ in PBS to reduce endogenous peroxidases and then with appropriate normal serum in PBS to reduce nonspecific staining. They were then treated with primary antibody for 72 hours in the cold. An exception was the Dako-T4 antibody for CD4 lymphocytes. This was used against fresh-frozen, cryostat cut, and acetone fixed tissue since normal fixation destroyed the surface antigen. Sections were next treated with a Vectastain $\mathrm{ABC}$ second antibody system corresponding to the primary antibody at dilutions recommended by the supplier (Vector Laboratories). Finally, they were incubated in a staining mixture containing $0.01 \%$ 3,3'-diaminobenzadine (DAB, Sigma), $0.6 \%$ nickel ammonium sulphate (Fisher), $0.05 \%$ immidazole and $0.0003 \% \mathrm{H}_{2} \mathrm{O}_{2}$ in $0.05 \mathrm{M}$ Tris-buffer $\mathrm{pH} 7.6 .14$, 19 Tissues were left in this staining mixture for 5 to 15 minutes before termination of the reaction by transferring to PBS. In cases where double immunostaining was carried out, excess peroxidase from the first cycle was destroyed by treating with $0.2 \% \mathrm{H}_{2} \mathrm{O}_{2}$ for 30 minutes prior to incubation with the second primary antibody. The steps were repeated as before, except that a different staining mixture was used in the final step. This consisted of $0.5 \%$ DAB and $.008 \% \mathrm{H}_{2} \mathrm{O}_{2}$ in $0.05 \mathrm{M}$ Tris-buffer to yield a brown reaction product. This product contrasted with the purple product from the first antibody reaction. Sections were dehydrated with graded alcohol, and, in some cases, counter-stained with neutral red before coverslipping with Entellan (Merck). 
Table 1: Antibody Source, Conditions of Staining and Results

\begin{tabular}{|c|c|c|c|c|}
\hline Antigen & Antibody Type & Source & $\begin{array}{l}\text { Concentration } \\
\text { Used for Staining }\end{array}$ & Results \\
\hline $\mathrm{Clq}$ & goat polyclonal & Cytotech & $1: 100,000$ dilution & plaques, tangles, neuropil threads, dystrophic neurites \\
\hline C3d & rabbit polyclonal & Dako & $1: 20,000$ dilution & $\begin{array}{l}\text { plaques, diffuse deposits, tangles, neuropil threads, } \\
\text { dystrophic neurites }\end{array}$ \\
\hline $\mathrm{C} 4 \mathrm{~d}$ & MAB & Cytotech & $2 \mathrm{micrograms} / \mathrm{ml}$ & $\begin{array}{l}\text { plaques, diffuse deposits, tangles, neuropil threads, } \\
\text { dystrophic neurites }\end{array}$ \\
\hline $\mathrm{C} 7$ & MAB & Cytotech & $3 \mathrm{micrograms} / \mathrm{ml}$ & plaques, tangles, neuropil threads, dystrophic neurites \\
\hline C9 & goat polyclonal & Cytotech & $1: 45,000$ dilution & plaques, tangles, neuropil threads, dystrophic neurites \\
\hline CSb-9 & MAB & Cytotech & 2 micrograms $/ \mathrm{ml}$ & dystrophic neurites, neuropil threads, tangles \\
\hline $\mathrm{Bb}$ & MAB & Cytotech & $5 \mathrm{micrograms} / \mathrm{ml}$ & no staining \\
\hline Properidin & MAB & Cytotech & $5 \mathrm{micrograms} / \mathrm{ml}$ & no staining \\
\hline HLA-A,B,C & MAB HB 120 & ATCC & $\begin{array}{l}\text { culture supernatant } \\
1: 200 \text { dilution }\end{array}$ & capillaries \\
\hline HLA-DR & MAB HB 104 & ATCC & $\begin{array}{l}\text { culture supernatant } \\
1: 1,000 \text { dilution }\end{array}$ & microglia trace; reactive microglia ++++ \\
\hline FcR $\gamma \mathrm{I}$ receptor & MAB 32.2 & Medarax & $1: 1,000$ dilution & microglia ++; reactive microglia ++++ \\
\hline FcR $\gamma \mathrm{Il}$ receptor & MAB & AMAC & $1: 300$ dilution & microglia + ; reactive microglia ++ \\
\hline $\begin{array}{l}\text { Leukocyte } \\
\text { common antigen }\end{array}$ & MAB & Dako & 1:100 dilution & leucocytes ++++ ; reactive microglia ++ ; microglia + \\
\hline $\begin{array}{l}\text { CD4 } \\
\text { (T4 helper } \\
\text { inducer) }\end{array}$ & MAB & Dako & 1:200 dilution & T4 lymphocytes; microglia trace \\
\hline $\begin{array}{l}\text { CD8 } \\
\text { (T8 cytotoxic } \\
\text { suppressor) }\end{array}$ & MAB & Dako & $1: 200$ dilution & T8 lymphocytes \\
\hline GFAP & rabbit polyclonal & Dako & $\mathrm{l}: 10,000$ dilution & reactive astrocytes $+++;$ astrocytes \pm \\
\hline
\end{tabular}

MAB = mouse monoclonal

Numerous controls were performed consisting of elimination of the primary antibody, or substitution of one of several solutions in its place. These included a mouse monoclonal antibody indifferent to brain tissue, normal mouse or rabbit serum, or monoclonal culture medium without antibody. No positive staining was observed with any of these control solutions.

\section{Results with Complement Antibodies}

Figures 1, 2 and 3 provide a brief summary of the complement system and how the various antibodies used in this study were designed to detect key components in the activation of the classical (Figures 1 and 2) or the alternative (Figure 3) pathways. For more details of the complement system, short ${ }^{12}$ or more comprehensive ${ }^{21}$ reviews are available. Complement consists of at least 20 proteins. The main components are the nine complex proteins designated $\mathrm{Cl}-\mathrm{C}$. They are produced in the liver and are present in serum, but they may also be produced by some tissue cells.

The classical complement pathway is initiated when $\mathrm{Cl}$ attaches to the Fc portion of an immunoglobulin (Figure $1 \mathrm{~A}$ ). Binding requires at least two IgG molecules or one IgM molecule. $\mathrm{Cl}$ is a loose aggregate consisting of the subcomponents $\mathrm{Clq}, \mathrm{Clr}$ and $\mathrm{Cls}$. The attachment of $\mathrm{Clq}$ activates $\mathrm{Clr}$, which in turn activates $\mathrm{Cls}$. Both $\mathrm{Clr}$ and $\mathrm{Cls}$ are serine proteinases. It is important to note that this process can be initiated by trypsin and other proteases so that the attachment of $\mathrm{Cl}$ and the activation of $\mathrm{Clr}$ and $\mathrm{Cls}$ do not require immunoglobulins. $\mathrm{C}$ 1s cleaves multiple molecules of the two complement proteins $\mathrm{C} 2$ and $\mathrm{C} 4$ into $\mathrm{a}$ and $\mathrm{b}$ fragments (Figure $1 \mathrm{~A}$ and $\mathrm{B}$ ). C2a can then join with $\mathrm{C} 4 \mathrm{~b}$ to become tissue bound near the site of acti- vation. The other fractions, $\mathrm{C} 4 \mathrm{a}$ and $\mathrm{C} 2 \mathrm{~b}$ are soluble and diffuse from the site.

The $\mathrm{C} 4 \mathrm{~b}$ portion is more strongly attached to tissue than Clq. It forms a covalent bond at a site different from, but near to, the $\mathrm{Clq}$ attachment site. The bound $\mathrm{C} 4 \mathrm{~b} 2 \mathrm{a}$ complex is a protease known as $\mathrm{C} 3$ convertase. It splits multiple molecules of $\mathrm{C} 3$ into the fragments $\mathrm{C} 3 \mathrm{a}$ and $\mathrm{C} 3 \mathrm{~b}$ (Figure $\mathrm{1C}$ ). C3b attaches to tissue at an adjoining site to $\mathrm{C} 4 \mathrm{~b}$ by a similar chemical bond formation. The trimolecular complex $\mathrm{C} 2 \mathrm{aC} 4 \mathrm{bC} 3 \mathrm{~b}$ forms the enzyme C5 convertase. This splits multiple C5 molecules into C5a and C5b. C5b can combine with C6 and C7. This C5b, 6, 7 complex may bury itself in the bilipid layer of the plasma membrane (Figure 1E). This becomes the initiation site for membrane attack by the membrane attack complex. Two molecules of C5b, 6, 7 may combine with two molecules of C8 and then 12-18 molecules of $\mathrm{C} 9$ to form the C5b-9 membrane attack complex itself (Figure $1 \mathrm{~F}$ ). The $\mathrm{C} 9$ components polymerize in a circular fashion, creating and then stabilizing a hole in the plasma membrane, thus promoting lysis and cell death. Meanwhile, both $\mathrm{C} 4 \mathrm{~b}$ and $\mathrm{C} 3 \mathrm{~b}$ degrade on the cell surface, eventually producing the residual components $\mathrm{C} 4 \mathrm{~d}$ and $\mathrm{C} 3 \mathrm{~d}$.

Thus, the antibody to $\mathrm{Clq}$ detects the residual component of activated $\mathrm{Cl}$; the antibodies to $\mathrm{C} 4 \mathrm{~d}$ and $\mathrm{C} 3 \mathrm{~d}$ detect the residual, covalently bound components of $\mathrm{C} 4$ and $\mathrm{C} 3$; the antibody to $\mathrm{C} 7$ detects the initial formation of the membrane attack complex (in addition to any soluble $\mathrm{C} 7$ ); the antibody to $\mathrm{C} 9$ detects the fully formed complex (in addition to any soluble C9); and the antibody to the neoantigenic site on C5b-9 detects only the fully formed complex. Amplification of the reaction can take place at the $\mathrm{Cl}, \mathrm{C} 2-\mathrm{C} 4, \mathrm{C} 3$, and $\mathrm{C} 5$ stages. The detection of $\mathrm{C} 4 \mathrm{~d}$ and 


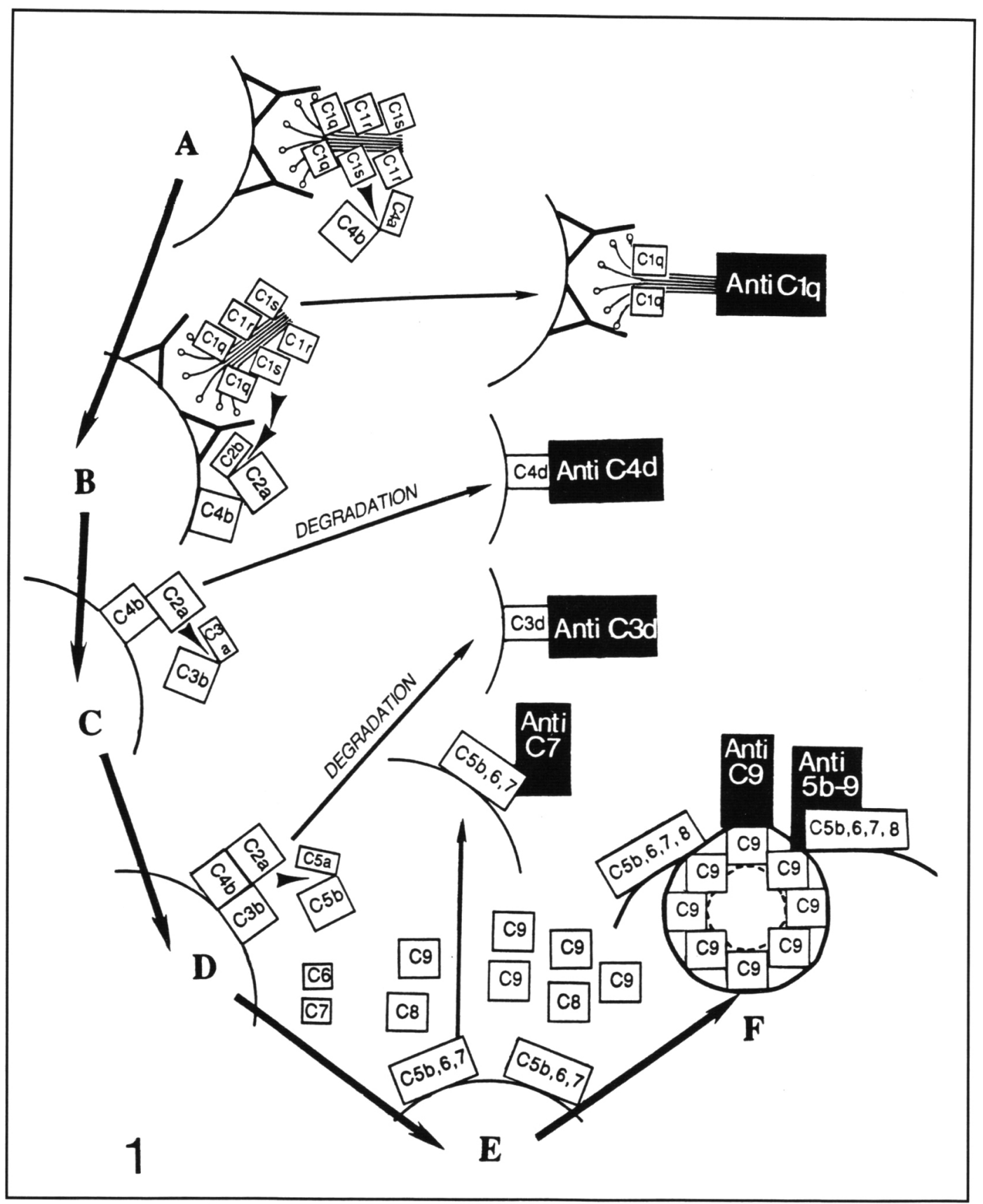

Figure I - Schematic diagram of the classical complement pathway. Complement proteins and their fragments are shown as rectangles or circles containing the appropriate designation. The antibodies used are indicated by the black rectangles. See text for details.

C3d is particularly important because it indicates that an ester or amide bond has been formed between the complement protein and tissue rather than a weak or non-specific attachment. The mechanism is shown in Figure 2. Both C4 and C3 have, in their soluble native form, a protected thioester site. This site becomes exposed upon activation. The thioester bond is cleaved, creating an active site which can react with tissue $\mathrm{OH}$ or $\mathrm{NH} 2$ bonds. The site is rapidly inactivated by soluble inhibitors if it fails to react with tissue $\mathrm{OH}$ and $\mathrm{NH}_{2}$ groups.

$\mathrm{C} 5 \mathrm{~b}, 6,7$ is also rapidly inactivated in the soluble state. Such inactivation is required to prevent lysis of bystander cells from taking place. Thus membrane attack only occurs when a suitable bilipid layer is available for C5b, 6, 7 attachment close to the site of the C5 convertase reaction. The antibody to C5b-9 recognizes a C9 epitope which appears only when the C5b-9 complex is assembled. It does not appear when inhibition at the C5b, 6, 7 stage takes place. Thus, complement activation may essentially terminate with the binding of $\mathrm{C} 3 \mathrm{~b}$. However, this in itself is an extremely important complement stage, since the attachment of C3b constitutes opsonization.

A very brief version of the alternative complement pathway is shown in Figure 3. The alternative pathway, originally described as the properdin system, does not require specific antibody but is effective in warding off infection. It requires the 


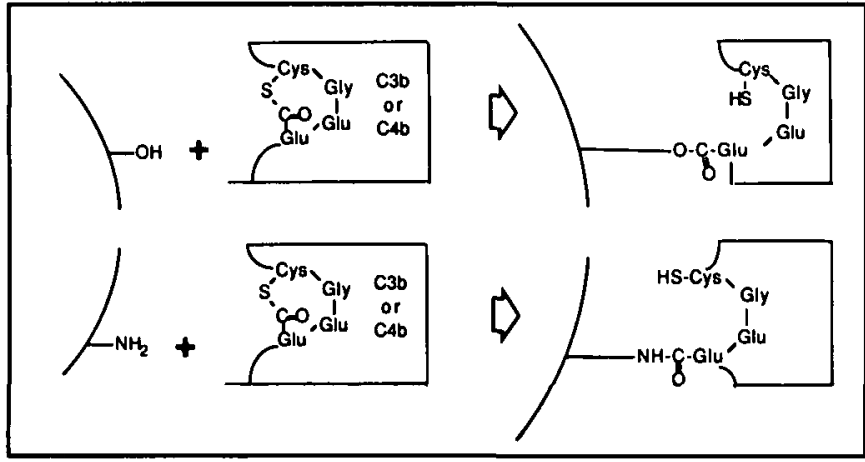

Figure 2 - Mechanism of attachment of complement fractions $C 3$ and C4 to tissue sites. The attachment process initially involves exposure of a protected thioester group through activation of the proteins. The exposed thioester group is then cleaved, providing an active site which may react with either an exposed $\mathrm{OH}$ or $\mathrm{NH} 2$ group on the target surface.

presence of $\mathrm{C} 3 \mathrm{~b}$ which is thought to be continuously present in small amounts in serum. When it is deposited on activators, it can interact with factors $B$ and $D$ to form an enzyme termed $\mathrm{C} 3 \mathrm{bBb}$. This complex is a $\mathrm{C} 3$ convertase which generates more $\mathrm{C} 3 \mathrm{~b}$, thus amplifying the system. Factor $\mathrm{P}$ or properdin can attach to the $3 \mathrm{bBb}$ complex to stabilize it. The formation of multiple molecules of $(\mathrm{C} 3 \mathrm{~b}) \mathrm{nBbP}$ can act as a C5 convertase, which is the first step in generating the membrane attack complex. Thus, C3 and its degradation products, as well as the components C5-9 appear in both the classical and alternative complement pathways. However, $\mathrm{Clq}$ and $\mathrm{C} 4 \mathrm{~d}$ are specific for the classical pathway, while fraction $\mathrm{Bb}$ of factor $\mathrm{B}$ and properdin are specific for the alternative complement pathway.

The results of tissue staining are shown in Figures 4-21, and are summarized in Table 1 . Staining of $A D$ subiculum by the Bielschowsky method, modified for greater sensitivity and to accommodate free floating sections, is shown in Figure 4. It demonstrates the numerous senile plaques and tangled neurons that are part of classical AD pathology. In addition, diffuse extracellular deposits of amyloid are revealed as background. Such diffuse deposits have recently been discovered through the development of antibodies specific for beta-amyloid protein. ${ }^{17,2-}$ 1-24 Some of these may precede the compact deposits that are detectable with classical Bielschowsky staining although many of them may simply be resolved. In Figure 4B many degenerating neurites associated with a plaque are visible. Plaques containing such neurites have been designated as primitive when associated with wisps of amyloid, and mature when associated with a definite amyloid core. They have been defined as burned out if only a dense amyloid core without neurites is visible. ${ }^{25}$ Positively staining neurites not associated with such plaques have been referred to as neuropil threads. ${ }^{26}$

Figures 5-12 show staining of AD temporal lobe with the various complement antibodies. Figure 5 demonstrates results on $\mathrm{AD}$ subiculum with the goat polyclonal antihuman $\mathrm{Clq}$ antibody. Staining of senile plaques, neurites within the plaques, tangled neurons and neuropil threads is obtained. Diffuse amyloid deposits do not stain, or are only very weakly stained.

Figure 6 shows similar tissue stained with the rabbit polyclonal antihuman $\mathrm{C} 3 \mathrm{~d}$ antibody. Comparable results are obtained.

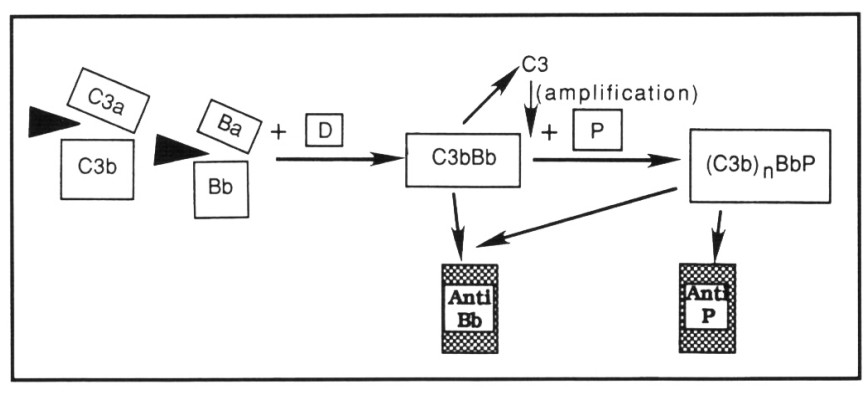

Figure 3 - Summary of the alternative complement pathway. As in Figure 1, complement proteins and their fragments are shown as clear rectangles, and the antibodies employed as black rectangles. See text for details.

Figure 7 is a photomontage showing staining of AD entorhinal cortex with the mouse monoclonal antibody to human $\mathrm{C} 4 \mathrm{~d}$. This antibody very strongly stains plaques, diffuse amyloid deposits, tangles, neuropil threads, and dystrophic neurites. Of the complement antibodies so far tested, it is the most sensitive in detecting pathologically altered tissue. Figure 8 shows staining of $\mathrm{AD}$ subiculum with the mouse monoclonal antibody to antihuman C7. Plaques are lightly stained along with tangles, neuropil threads and dystrophic neurites. Similar staining is obtained with the goat polyclonal antibody to antihuman C9 (Figure 9).

More discrete staining is obtained with the mouse monoclonal antibody to a neoantigenic site on human C5b-9 (Figure 10). Extracellular amyloid, either in the form of plaques or diffuse deposits, is not stained by this antibody. Only membrane containing structures such as dystrophic neurites and neuropil threads are stained as well as the tangles in some tangle containing neurons.

In contrast to staining with antibodies to the major components of the classical complement pathway, no staining was obtained with fraction Bb of Factor B (Figure 11) or properdin (Figure 12). These are antibodies specific for the alternative complement pathway.

\section{Results with Antibodies to Specific Cellular Markers}

Staining of AD tissue with antibodies to specific cellular markers is shown in Figures 13-20. Figure 13 shows staining with the mouse monoclonal antibody to the common structural

Figure 4-Bielschowsky staining of Alzheimer subiculum by the modified free floating technique to enhance sensitivity. The concentration of silver nitrate was reduced from the normal $20 \%$ to $1 \%$. The stained section was immersed in 5\% sodium thiosulfate for 5 minutes before mounting. A. The figure displays diffuse amyloid deposits in addition to the typically recognized senile plaques, neurofibrillary tangles and neuropile threads. $\boldsymbol{B}$. Enlarged plaque area shows a senile plaque containing intensely stained dystrophic neurites. Bars in $4 A-7 A=50 \mu \mathrm{m}, 4 B-7 B=10 \mu \mathrm{m}$

Figure 5 - Alzheimer subiculum stained with the antibody to $\mathrm{Cl}$. Similar staining is obtained to that with the Bielschowsky silver method except that diffuse amyloid deposits are not revealed. $A$. Low power. B. High power plaque area.

Figure 6-Staining of Alzheimer subiculum with the antibody to C3d. Similar staining to that with $\mathrm{Clq}$ is obtained except that amyloid deposits are more intensely stained. A. Low power. B. High power plaque area. 


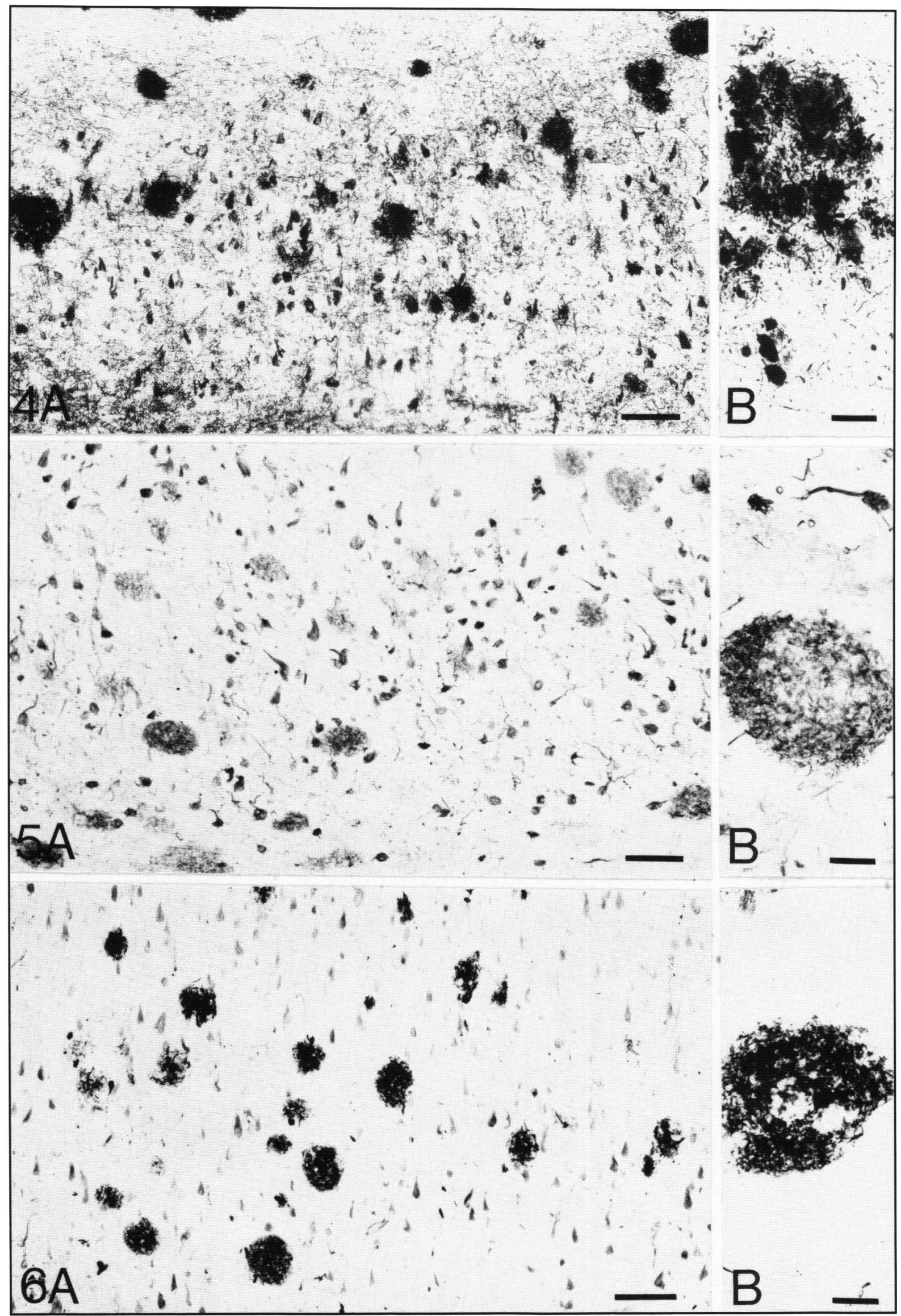




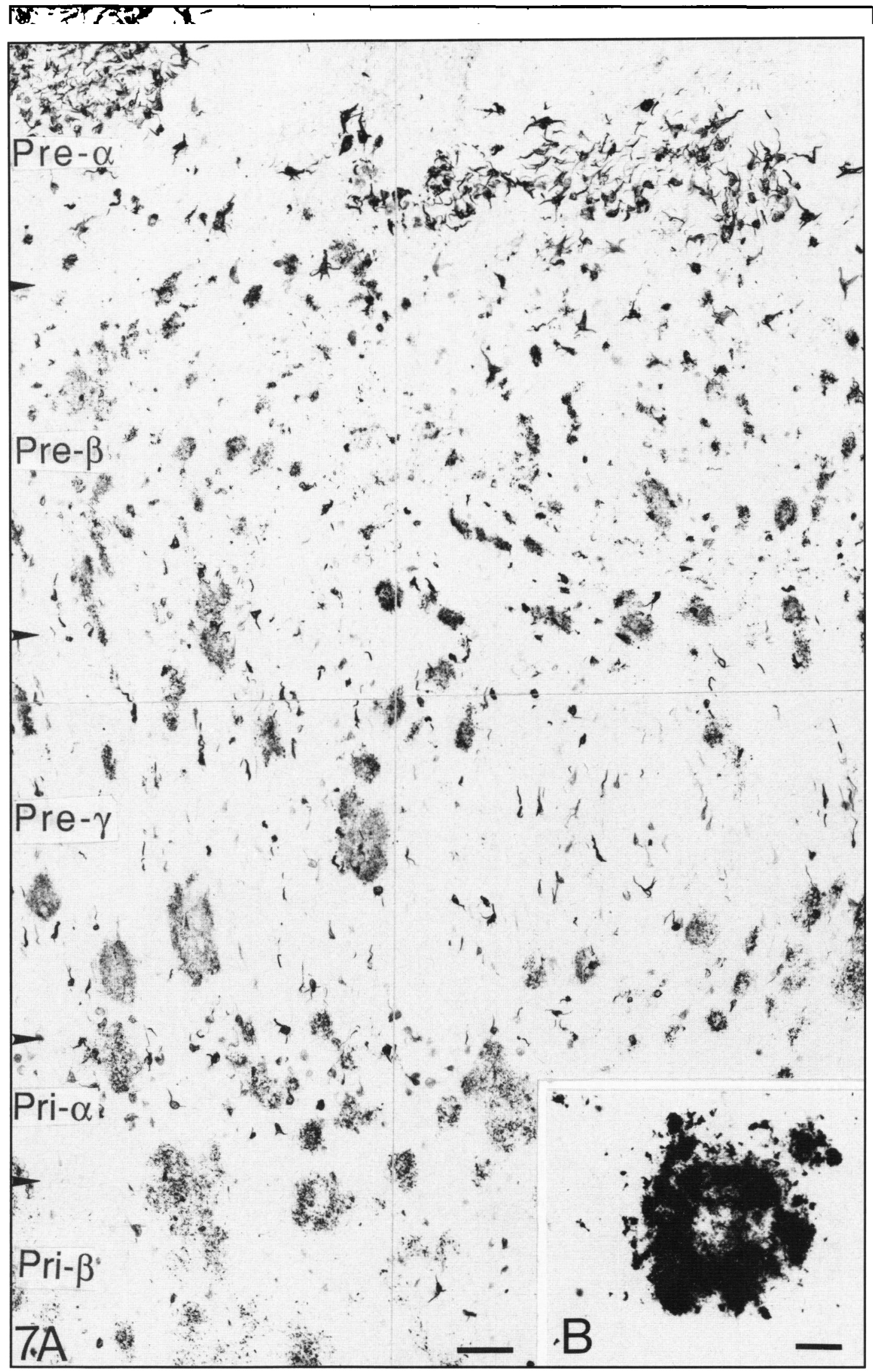

Figure 7-A. Staining of Alzheimer entorhinal cortex from layers Pre- $\alpha$ to Pri- $\beta$ with the antibody to C4d. Similar staining to that observed with C3d is obtained, except that a sharper outline of pathological elements is obtained. Notice the heavy tangle accumulation in the Pre- $\alpha$ and Pri- $\alpha$ layers, as well as the scattered, diffuse amyloid deposits in the Pre- $\beta$ layer. $\boldsymbol{B}$. High power plaque area. 


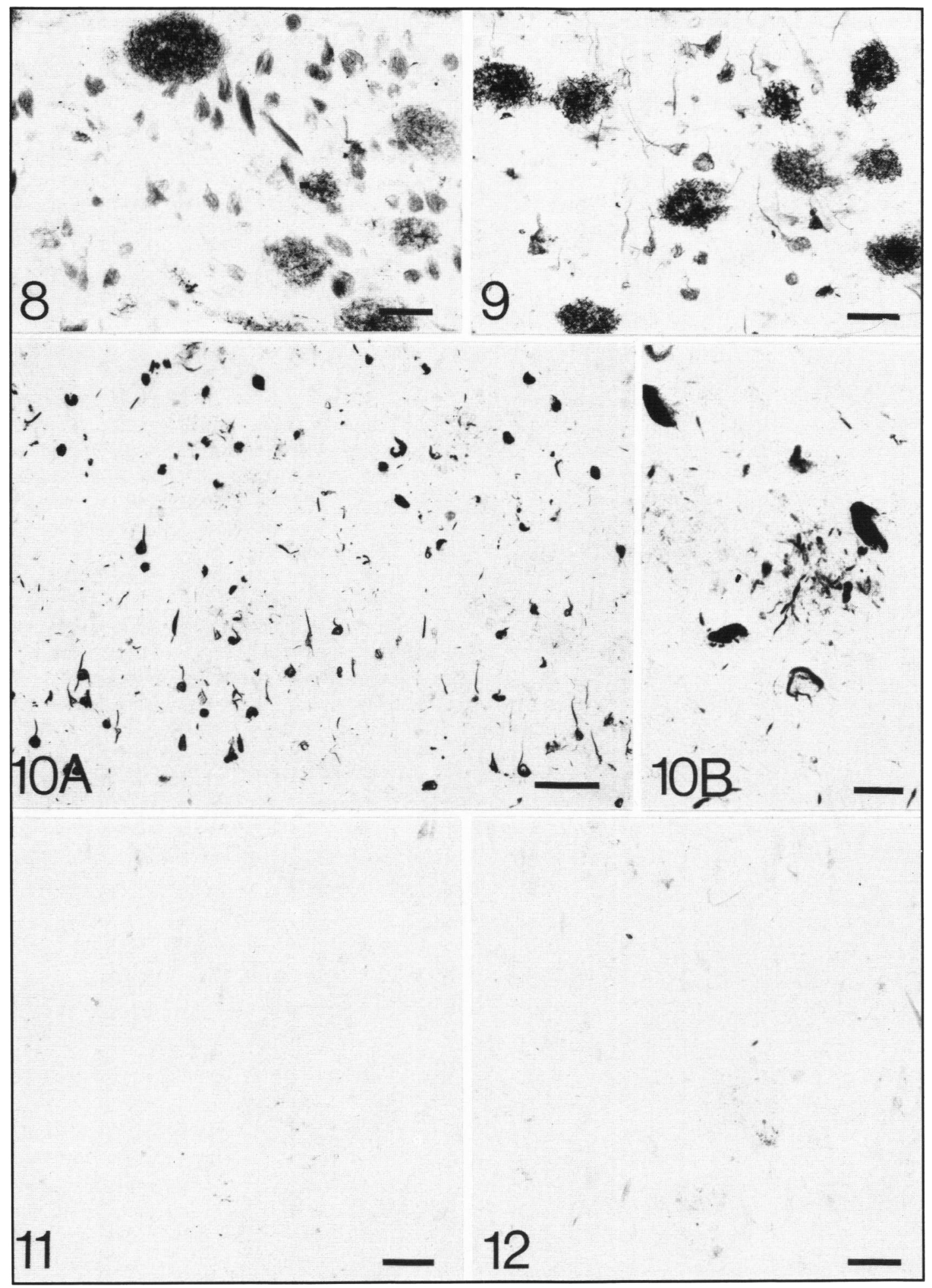

Figure 8-Staining of Alzheimer subiculum with the antibody to C7. Staining of dystrophic neurites and neuropile threads is visible as well as relatively light staining of senile plaques. Bar $=50 \mu \mathrm{m}$.

Figure 9-Staining of Alzheimer subiculum with the antibody to C9. Similar staining to that observed with the antibody to C7 is obtained. Bar $=50$ $\mu \mathrm{m}$.

Figure $10-A$. Staining of Alzheimer subiculum with the antibody to a neoantigenic site on C5b-9. Some tangles, dystrophic neurites, and senile plaques are prominently stained. Extracellular amyloid deposits are not stained with this antibody. B. High power photomicrograph of a typical senile plaque showing staining of the dystrophic neurites within the plaque, but not the amyloid deposit itself. Bar $=50 \mu \mathrm{m}$ in $A, 10 \mu \mathrm{m}$ in $B$.

Figure 11 - Staining of Alzheimer subiculum with the antibody to fraction Bb of factor B. No positive staining is observed. Bars in Figures $11-23=$ $10 \mu \mathrm{m}$.

Figure 12 - Staining of Alzheimer subiculum with the antibody to properdin (Factor $P$ ). No positive staining is observed. 


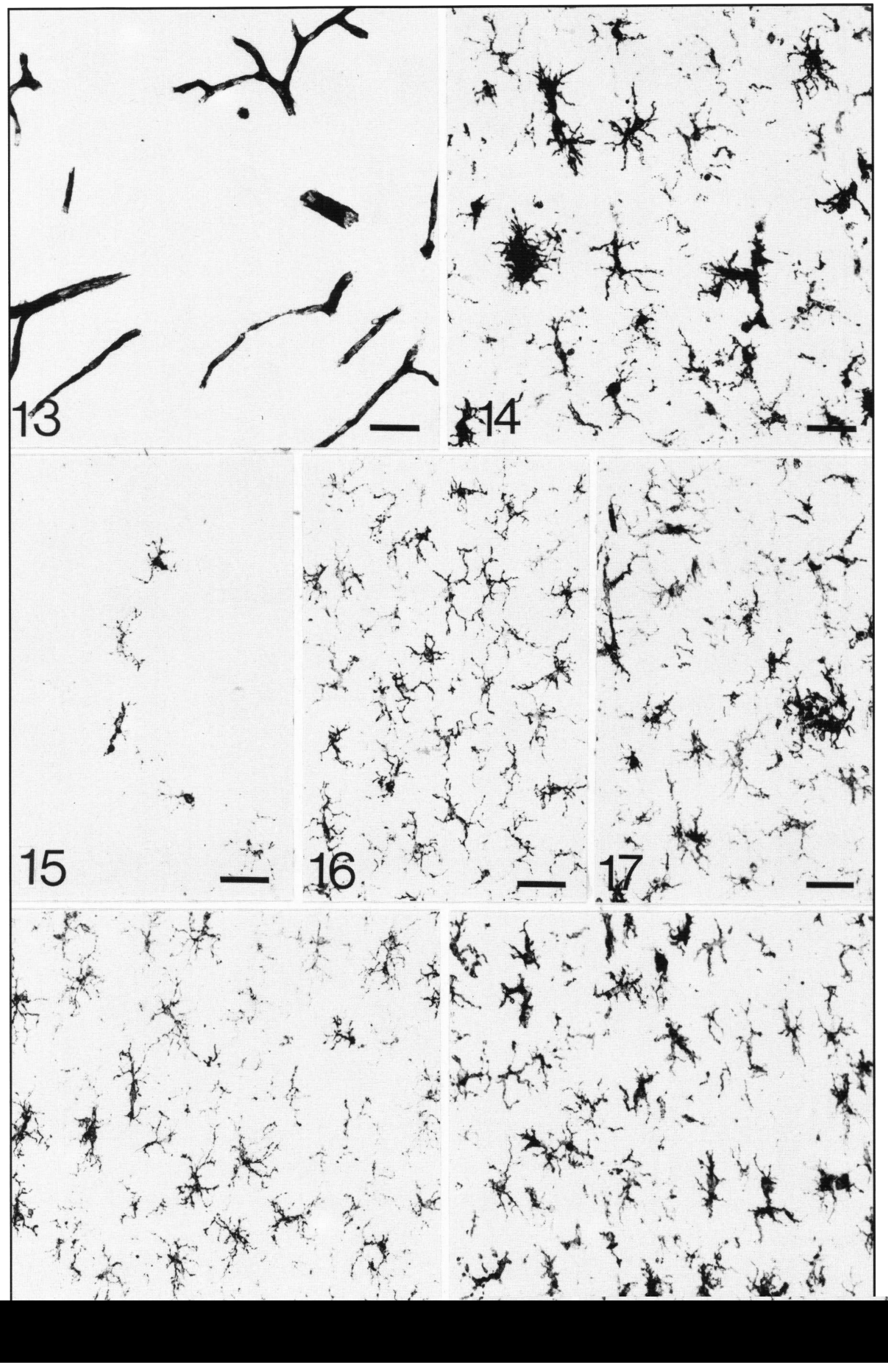


Figure 13 - Staining of Alzheimer midtemporal gyrus with the HB I20 cell line (antiHLA-A,B,C) antibody. Capillary endothelium is strangly positive.

Figure 14 - Alzheimer midtemporal gyrus stained with the HBI04 cell line (antiHLA-DR) antibody. Reactive microglial cells stain positively.

Figure 15 - Control midtemporal gyrus stained with the anti-HLA-DR antibody. Only a few microglia with resting morphology are stained.

Figure 16 - Staining of a nearby section to that shown in Figure 15 of control midtemporal gyrus with the antibody to leucocyte common antigen. Resting microglial cells can be seen to stain positively.

Figure 17-Alzheimer midtemporal gyrus stained with the antibody to leucocyte common antigen. Reactive microglia are strongly positive compared with the more faintly staining resting microglia.

Figure 18 - Staining of control midtemporal gyrus with the antibody to the FcyRI receptor. This section is nearby to those shown in Figures 15 and 16. Resting microglia stain positively.

Figure 19-Staining of Alzheimer midtemporal gyrus with the FcyRl receptor antibody. Resting microglia are stained and reactive microglia are intensely stained.

component of the group I major histocompatibility complex glycoproteins HLA-A, B, C. The vascular endothelial cells of capillaries are strongly stained in $\mathrm{AD}$ as well as control tissue. The mouse monoclonal antibody to the group II MHC glycoprotein HLA-DR strongly stains reactive microglia. These are particularly prominent in association with senile plaques (Figure 14), but they are also seen in other regions of gray matter, and more prominently in white matter of AD tissue. In control tissue, there is only occasional staining of microglia, usually in white matter, with morphology of the cells resembling resting microglia (Figure 15). Some leukocytes and some capillaries in $\mathrm{AD}$ tissue are also positively stained with this antibody.

Figures 16 and 17 show staining of the midtemporal gyrus of control and AD tissue with the mouse monoclonal antibody to human leukocyte common antigen. This antibody stains all leukocytes as well as resting and reactive microglia. Leukocytes are strongly stained, reactive microglia moderately stained, and resting microglia weakly stained. The section of control tissue in Figure 16 is nearby to that shown in Figure 15. Many more microglia than in Figure 16 are stained, although the morphology is comparable. Figure 17 shows staining of an AD case. Intensely positive reactive microglia are prominent, including one agglomeration which is probably associated with a senile plaque.

Figures 18 and 19 show staining of control and AD midtemporal gyrus, respectively, with the monoclonal antibody to the FcyRI receptor. All microglia prominently stain with this antibody. Normal peripheral blood monocytes have 15,000-40,000 FcyRI sites per cell, while macrophages have more than 50,000 sites per cell. ${ }^{27} \mathrm{High}$ constitutive levels of this receptor on microglia probably account for the prominent staining of resting microglia in control tissue, as shown in Figure 18. Reactive microglia are much more intensely stained as demonstrated in Figure 19. Presumably, inflammatory stimulation substantially enhances the expression of the FcyRI receptor.

Figure 20 shows staining with an antibody to the Fc $\gamma$ RII receptor. This receptor is expressed on all leukocyte cell lines including platelets, and is therefore not as characteristic of monocyte lineage as is the FcyRI receptor. Nevertheless, some staining of resting and reactive microglia is obtained with the antibody to this receptor.

Figure 21 shows double immunostaining of AD hippocampus with the antibody to HLA-A, B, C and the antibody to the CD8 $\mathrm{T}$ lymphocyte subset. In the original section, CD8 staining was purple and the HLA-A, B, C was brown. T8 lymphocytes can be seen marginating along the walls of post capillary venules with a few infiltrating the tissue matrix.

Figure 22 shows staining with the CD4 antibody of T-4 lymphocytes. Since the epitope recognized by the antibody does not survive paraformaldehyde fixation, this particular staining was performed on a cryostat cut section that had been taken up directly on a glass slide. The morphology is not of the same standard as seen in the other photomicrographs, but T-4 positive cells can be seen in capillaries and in the matrix. Microglia stain very lightly with this antibody.

Figure 23 shows staining of AD tissue with the polyclonal antibody to GFAP. Astrocytes, many of them hypertrophic, are prominently stained. We have previously described the relationship between astrocytes, HLA-DR reactive microglia and senile plaques. 15,17 Reactive astrocytes are a different population from the reactive microglia. The reactive astrocytes in Figure 23 are gathered around the periphery of senile plaques.

\section{Discussion}

These results clearly demonstrate complement activation of pathologically altered tissue in AD disease. Plaques, tangled neurons, dystrophic neurites and neuropil threads are stained by all, or some, of the main components of the classical complement pathway. The full classical, but not the alternative complement pathway, is activated in AD brain tissue. However, the mechanism of activation is unknown. Immunoglobulins interacting with their target antigen are usually responsible for complement activation. However, clear cut evidence of immunoglobulin staining of AD tissue has not yet been obtained, and therefore other possibilities must be considered. Trypsin-like enzymes are known to be able to initiate the complement cascade, and it is possible that some unidentified protease starts the process.

Extracellular amyloid is clearly a target for complement proteins, perhaps for the purpose of opsonization. However, such a process terminates at the $\mathrm{C} 3$ stage. Our results demonstrate that subsequent stages are involved. Dystrophic neuronal processes and neuropil threads could provide a bilipid membrane for $\mathrm{C5b}$, 6, 7 attachment and therefore assembly of the membrane attack complex. The positively staining dystrophic neurites could be targeted for membrane attack and cell lysis but they could also fall into the bystander category and be victims of amyloid opsonization. Since neuropil threads often appear at sites remote from extracellular amyloid, and since the $\mathrm{Cl}-\mathrm{C} 4$ components of complement also stain these structures, the bystander interpretation seems less likely than specific targeting.

The previous reports of equivocal IgG staining of senile plaques, and the failure of $\mathrm{Clq}$ to stain diffuse amyloid deposits could be related to two factors. The first is weak affinity. The attachment of immunoglobulins to antigen, and the attachment of $\mathrm{Cl}$ to the $\mathrm{Fc}$ chain are both relatively weak in binding affinity. Thus, the complexes might not survive the preparation of the tissue as well as the $\mathrm{C} 4$ and $\mathrm{C} 3$ fragments which bind covalently to tissue. The second is lack of amplification at the $\operatorname{lgG}$ and $\mathrm{Cl}$ 


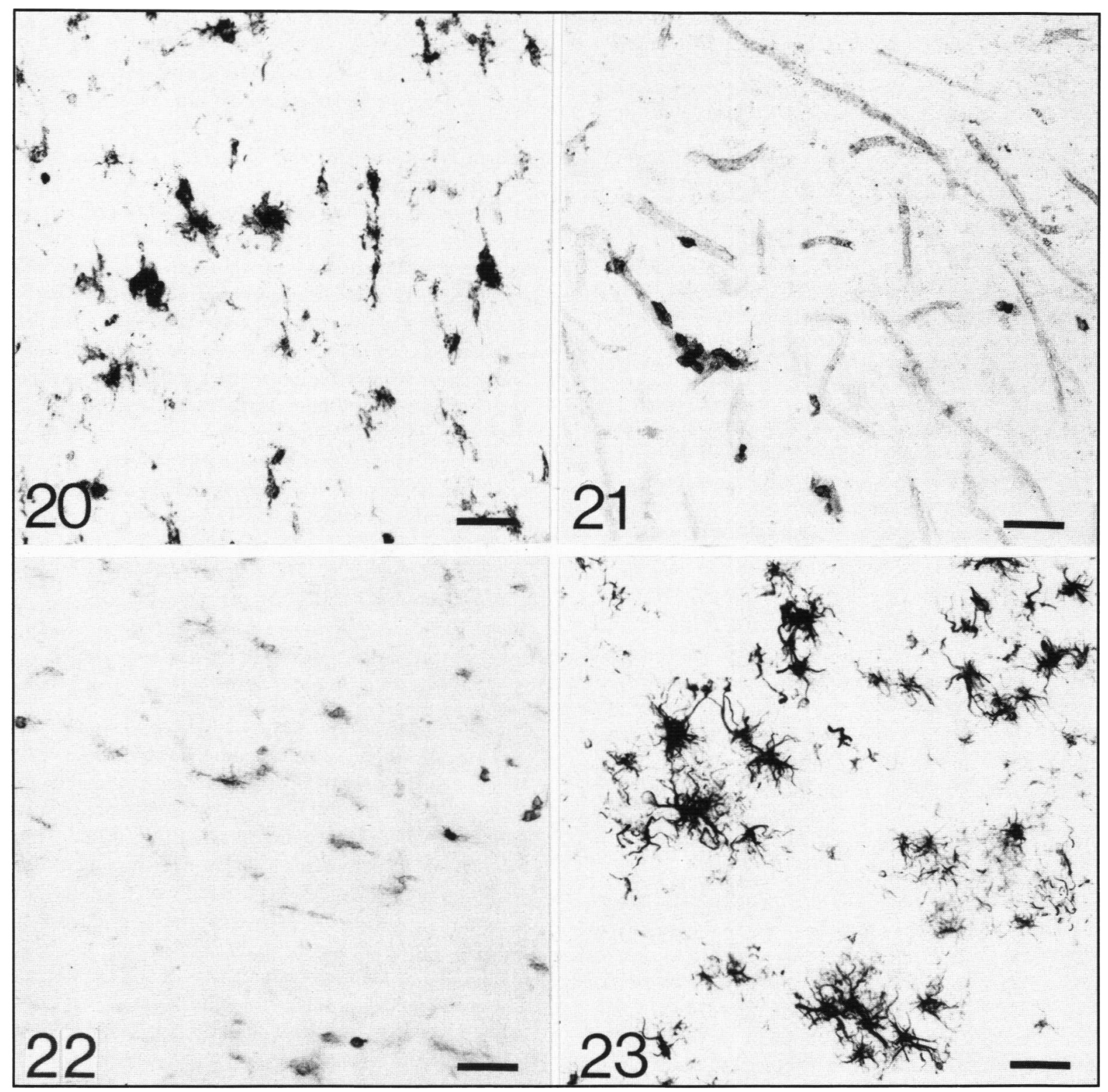

Figure 20 - Staining of Alzheimer angular gyrus with the FcyRII receptor antibody. Less discrete staining of reactive microglia, compared to that seen with the $F c Y R I$ antibody is obtained. Resting microglia are only very weakly stained.

Figure 2I - Alzheimer parahippocampal gyrus doubly immunostained for T8 lymphocytes and class I MHC (HLA-A,B,C) antigens. Light neutral red counterstaining. Class I positivity is confined to the capillaries, while T8 cells can be seen marginating along the walls of the capillary and invading the tissue matrix.

Figure 22 - Cryostat cut section of fresh Alzheimer parahippocampal gyrus stained with the antibody to T-4 lymphocytes. A few positively staining lymphocytes are visible. The capillary endothelium, and some tissue microglia are seen to stain very lightly.

Figure 23 - Alzheimer angular gyrus stained with the antibody to glial fibrillary acidic protein. Astrocytes are the only positively staining structures. Several clusters of hypertrophied, intensely staining, reactive astrocytes are visible. These are probably located around the margins of senile plaques.

stages. Considerable amplification is possible at the $\mathrm{C} 4, \mathrm{C} 3$, and C5 stages, as well as at the $C 9$ polymerization stage. Such amplification may be critical to immunohistochemical detection.

All of the appropriate cellular elements of an immune response are present in $\mathrm{AD}$ tissue. Reactive microglia are the most prominent inflammatory cell population. They are characterized not only by the altered morphology originally described by Del Rio Hortega, but by enhanced expression of such surface proteins as the Fc $\gamma \mathrm{RI}$ and Fc $\gamma \mathrm{RII}$ receptors and MHC class II glycoproteins. The Fc receptors are presumably related to their phagocytotic function, while the MHC glycoproteins may be for the purpose of attracting $\mathrm{T}$ lymphocytes.

We have previously reported on the preferential, but not exclusive, association of reactive microglia with senile plaques in $\mathrm{AD}$ disease. ${ }^{14,15,17}$ Reactive microglia are also found in gray matter areas associated with tangled neurons and dystrophic neurites at sites distinct from senile plaques themselves.

The occurrence of T4 and T8 lymphocytes in AD tissue is consistent with enhanced MHC expression in affected tissue. ${ }^{19}$ The exact role of the T lymphocytes is unknown, but is presum- 
ably related to the traditional functions that have been associated with their presence in chronically inflamed tissue.

Several previous studies have suggested the existence of humoral antibodies directed against AD brain tissue. Gaskin et al $^{28}$ and Singh and Fudenberg ${ }^{29}$ detected interaction between AD serum and brain tissue by immunofluorescence microscopy. Foley et $\mathrm{al}^{30}$ and Bradford et al (this symposium) were able to detect specific lysis of rat brain cholinergic synaptosomes using AD serum plus complement. Fillit et al $^{31}$ found antivascular and Chapman et al ${ }^{32}$ anticholinergic neuron antibodies in the serum of patients with AD. McRae-Deguerce et al ${ }^{33}$ found antibodies to cholinergic neurons in the CSF of some AD patients. All of these data suggest that specific antibodies are being produced against neuronal elements in AD. The extent to which these may be responsible for the phenomena observed in this study are subjects for future research.

\section{ACKNOWLEDGEMENT}

This research was supported by grants from the Alzheimer Society of B.C., the Medical Research Council of Canada and the American Health Assistance Foundation.

\section{REFERENCES}

1. Ishii T, Haga S, Shimizu F. Identification of components of immunoglobulins in senile plaques by means of fluorescent antibody technique. Acta Neuropathol (Berl) 1975; 32: 157-162.

2. Ishii T, Haga S. Immuno-electron microscopic localization of immunoglobulins in amyloid fibrils of senile plaques. Acta Neuropathol (Berl) 1976; 20: 372-378.

3. Ishii $T$, Haga $S$. Immuno-electron microscopic localization of complements in amyloid fibrils of senile plaques. Acta Neuropathol (Berl) 1984; 63: 296-300.

4. Ishii T, Haga S, Kametani F. Presence of immunoglobulins and complements in the amyloid plaques in the brain of patients with Alzheimer's disease. In: Pouplard-Barthelaix A, Emile J, Christen Y, eds. Berlin Heidelberg: Springer-Verlag, 1988: 1729.

5. Ihara Y, Kurizaki H, Nukina N, et al. Presence of immunoglobulin light chain in the cores of senile plaques - an unlabelled antibody peroxidase-antiperoxidase (PA) study. Neurol Med (Japan) 1981; 15: 292-295.

6. Eikelenboom P, Stam FC. Immunoglobulins and complement factors in senile plaques. Acta Neuropathol (Berl) 1982; 57: 239242.

7. Powers JM, Schlaepfer WW, Willingham MC, et al. An immunoperoxidase study of senile cerebral amyloidosis with pathogenetic considerations. J Neuropathol Exp Neurol 1981; 40: 592-612

8. Eikelenboom P, Hack CE, Rozemuller JM, et al. Complement activation in amyloid plaques in Alzheimer's dementia. Virchows Archiv [Cell Pathol] 1980; 56: 259-262.

9. Alafuzoff I, Adolfsson R, Grundke-Iqbal I, et al. Blood-brain barrier in Alzheimer dementia and in non-demented elderly. Acta Neuropathol (Berl) 1987; 73: 160-166.

10. Mann DMA, Yates PO, Hawkes J. Plaques and tangles and transmitter deficiencies in dementia. J Neurol Neurosurg Psychiatry 1982; 45: 563-564

11. Pouplard-Barthelaix A. Immunological markers and neuropathological lesions in Alzheimer's disease. In: Pouplard-Barthelaix A, Emile J, Christen Y, eds. Berlin Heidelberg: Springer-Verlag, 1988: 7-16.
12. Cooper NR. The complement system. In: Stites DP, Stobo JD, Wells JV, eds. Basic and Clinical Immunology, 6th ed. Norwalk: Appleton \& Lange, 1987: 114-127.

13. Lampson LA. Molecular bases of the immune response to neural antigens. TINS 1987; 10: 211-216.

14. McGeer PL, McGeer EG, Itagaki S, et al. Anatomy and pathology of the basal ganglia. Can J Neurol Sci 1987; 14: 363-372.

15. McGeer PL, Itagaki $\mathrm{S}$, Tago $\mathrm{H}$, et al. Reactive microglia in patients with senile dementia of the Alzheimer's type are positive for the histocompatibility glycoprotein HLA-DR. Neurosci Lett 1987; 79: 195-200.

16. Rogers J, Luber-Narod J, Styren SD, et al. Expression of immune system-associated antigen by cells of the human central nervous system. Relationship to the pathology of Alzheimer's disease. Neurobiol Aging 1988; 9: 330-349.

17. Itagaki S, McGeer PL, Akiyama H, et al. Relationship of microglia and astrocytes to amyloid deposits in Alzheimer's disease. $J$ Neuroimmunol (in press).

18. Stites DP, Stobo JD, Wells JV. Basic and Clinical Immunology, 6th ed. Norwalk: Appleton \& Lange, 1987.

19. Itagaki S. McGeer PL, Akiyama H. Presence of T-cytotoxic suppressor and leucocyte common antigen positive cells in Alzheimer's disease brain tissue. Neurosci Lett 1988; 91: 259264.

20. Luber-Narod J, Rogers J. Immune system associated antigens expressed by cells of the human central nervous system. Neurosci Lett 1988; 94: 17-22.

21. Rother K, Till GO, eds. The Complement System. Berlin, Heidelberg: Springer-Verlag, 1988.

22. Ikeda SI, Allsop D, Glenner GG. Morphology and distribution of plaque and related deposits in the brains of Alzheimer's disease and control cases. Lab Invest 1989; 60: 113-119.

23. Ogomori $\mathrm{K}$, Kitamoto $\mathrm{T}$, Tateishi $\mathrm{J}$, et al. $\boldsymbol{\beta}$-Protein amyloid is widely distributed in the central nervous system of patients with Alzheimer's disease. Am J Pathol 1989; 134: 243-251.

24. Yamaguchi $H$, Hirai S, Morimatsu M, et al. A variety of cerebral amyloid deposits in the brains of the Alzheimer-type dementia demonstrated by $\beta$ protein immunostaining. Acta Neuropathol 1988; 76: 541-549.

25. Wisniewski HM, Terry RD. Reexamination of the pathogenesis of the senile plaque. In: Zimmer HM, ed. Progress in Neuropathology. New York: Grune and Stratton, 1973: 1-26.

26. Braak H, Braak E. Neuropil threads occur in dendrites of tanglebearing nerve cells. Neuropathol Appl Neurobiol 1988; 14: 3944.

27. Fanger MW, Shen L, Graziano RF, et al. Cytotoxicity mediated by human Fc receptors for IgG. Immunol Today 1989; 10: 92-99.

28. Gaskin F, Kingsley BS, Fu SM. Autoantibodies to neurofibrillary tangles and brain tissue in Alzheimer's disease. J Exp Med 1987; 165: 245-250.

29. Singh VK, Fudenberg HH. Detection of brain autoantibodies in the serum of patients with Alzheimer's disease but not Down's syndrome. Immunol Lett 1986; 12: 277-280.

30. Foley $\mathrm{P}$, Bradford HF, Docherty $\mathrm{M}$, et al. Evidence for the presence of antibodies to cholinergic neurons in the serum of patients with Alzheimer's disease. J Neurol 1988; 235: 466-47I.

31. Fillit H, Luine VN, Reisberg B, et al. Studies of the specificity of antibrain antibodies in Alzheimer's disease. In: Hutton JT, Kenny AD, eds. Senile Dementia of the Alzheimer's Type. New York: Liss, 1985: 307-318.

32. Chapman J, Bachar O, Korczyn AD, et al. Antibodies to cholinergic neurons in Alzheimer's disease. J Neurochem 1988; 51 : 479. 485.

33. McRae-Degueurce A, Booj S, Haglid K, et al. Antibodies in cerebrospinal fluid of some Alzheimer disease patients recognize cholinergic neurons in the rat central nervous system. Proc Natl Acad Sci USA 1987; 84: 9214-9218. 